\title{
The Synthesis of Polysaccharides by Bacteria Isolated from Soil
}

\author{
By W. G. C. FORSYTH AND D. M. WEBLEY \\ Macaulay Institute for Soil Research, Craigiebuckler, Aberdeen
}

SUMMARY: Bacteria capable of synthesizing polysaccharides are present in various agricultural, moorland and forest soils, and may form from 5-16\% of the viable bacterial population, as estimated by the plate-dilution counting technique. Chemical examination of the polysaccharides synthesized distinguished four types: levans, glucose-uronic acids, glucose-mannose-uronic acids and glucose-mannose-rhamnoseuronic acids. Bacteria synthesizing these polysaccharides are well distributed in the soils studied, those forming the first two types being by far the most common. There is no clear relationship between morphology of the organisms and type of polysaccharide synthesized.

It has been suggested (Norman, 1942) that the uronide carbon of soil organic matter may be in part derived from microbial polysaccharides. Indirect evidence in support of this hypothesis has been brought forward by Fuller (1947), and Forsyth (1947) isolated from soils a definite polysaccharide fraction which contained uronic acid units. Although an important role in determining the physical structure of soils has been suggested for bacterial polysaccharides (Martin, 1946), little has been done in isolating the bacteria in soil which are capable of synthesizing polysaccharides, or in determining the nature of the polysaccharides produced. Martin (1945) has made a start in this direction. He found, using a medium containing egg-albumin, or sodium nitrate and glucose or sucrose, and pouring plates from a high dilution, that nearly every plate contained from one to five slimy colonies. The majority of the organisms forming these colonies were capsulated. We have surveyed different soils (agricultural, moorland, and forest) to determine $(a)$ the presence, and if possible the proportion, of gum-producing bacteria, and $(b)$ the nature of the polysaccharides produced by these organisms.

\section{METHODS}

Bacteriological methods. The medium used throughout this work was that of Cooper \& Preston (1937), called by them Medium II. For counting purposes the $\mathrm{CaCO}_{3}$ which this medium ordinarily contains can be omitted. Soil samples were taken with sterile precautions and plated by the dilution technique of Cutler, Crump \& Sandon (1922) on the day the samples were collected, and usually incubated from 3-4 days at $25^{\circ}$. With longer incubation the plates were frequently overgrown by spreading organisms. The sucrose, used in $2 \%$ concentration in the medium, was sterilized separately at double strength and $4 \mathrm{ml}$. added to an equal quantity of double-strength mineral base + agar.

The proportion of slimy colonies was noted and each colony examined for capsulated organisms before inclusion in the count. From among these colonies (developing on the five replicate plates) random isolations were then made on 
to Cooper \& Preston's solid medium. Pure cultures obtained on this medium were grown for $2-4$ days at $25^{\circ}$ on four plates of the same medium and the growth harvested for investigation.

Chemical methods. The polysaccharides were purified and hydrolysed as described by Forsyth \& Webley (1949) and the constituent sugars identified by the paper chromatography technique (Partridge, 1946, 1948; Forsyth, 1948) as follows.

Fructose. After hydrolysis with $0.1 \mathrm{~N}-\mathrm{H}_{2} \mathrm{SO}_{4}$ for $\frac{1}{2} \mathrm{hr}$. at $100^{\circ}$, fructose was identified from its $R_{F}$ values ( $n$-butanol, $0 \cdot 10$; phenol, $0.51 ; s$-collidine, $0 \cdot 42$ ), and confirmed by the ketose reaction on spraying the chromatograms with naphthoresorcinol or resorcinol reagent. When fructose was present it was destroyed by dilute acid hydrolysis of another sample of the gum and the residual polysaccharide, if any, reprecipitated with ethanol and subjected to stronger hydrolysis $\left(\mathrm{N}_{-} \mathrm{H}_{2} \mathrm{SO}_{4}\right.$ for $4 \mathrm{hr}$.) to test for other sugars. When fructose was not present, another sample of gum was directly hydrolysed with the $\mathrm{N}-\mathrm{H}_{2} \mathrm{SO}_{4}$ for the other sugars. Only $10-20 \mathrm{mg}$. samples were required.

Glucose. $R_{F}$ values: $n$-butanol, $0 \cdot 07$; phenol, $0 \cdot 39 ; s$-collidine, $0 \cdot 39$. That the sugar was an aldohexose was confirmed by resorcinol spray.

Mannose. $R_{F}$ values : $n$-butanol, $0 \cdot 10$; phenol, $0 \cdot 45 ; s$-collidine, $0 \cdot 46$. That the sugar was an aldohexose was confirmed by resorcinol spray.

Rhamnose. $R_{F^{\prime}}$ values: $n$-butanol, 0.22 ; phenol, $0.59 ; s$-collidine, 0.59 . That the sugar was a methylpentose was confirmed by naphthoresorcinol and resorcinol spray.

Uronic acids. These were detected both by the naphthoresorcinol test on the intact polysaccharide and by spraying chromatograms of the hydrolysate with this reagent. They also give spots close to the starting line with the silver nitrate reagent.

\section{RESULTS}

From Table 1 it will be seen that the polysaccharide-producing bacteria were present in all three types of soil examined. The proportion varied from about $5 \%$ of the total viable bacterial flora in the $B_{1}$ layer of the moorland soil to about $16 \%$ in the top 6 in. of the agricultural soil. From the soils listed in Table 1 and from one other agricultural soil 40 strains were isolated at random from the slimy colonies on the plates. Table 2 gives a complete list of the

Table 1. Gum-producing bacteria in soils

\begin{tabular}{|c|c|c|c|c|c|}
\hline \multicolumn{2}{|l|}{ Soil sample } & \multirow{2}{*}{$\begin{array}{l}\text { Dilution used } \\
\text { for plating }\end{array}$} & \multicolumn{2}{|r|}{$\begin{array}{l}\text { Mean count } \\
\text { (3-5 plates) }\end{array}$} & \multirow{2}{*}{$\begin{array}{l}\text { Proportion } \\
\text { of gum-pro- } \\
\text { ducing } \\
\text { bacteria } \\
(\%)\end{array}$} \\
\hline Location and type & Depth & & Total & Gummy colonies & \\
\hline Moorland (Dinnet) & $\begin{array}{l}A_{2}{ }^{*} \text { layer } \\
B_{1} * \text { layer }\end{array}$ & $\begin{array}{l}1 / 2,500 \\
1 / 2,500\end{array}$ & $\begin{array}{r}120 \\
73\end{array}$ & $\begin{array}{r}13 \\
5\end{array}$ & $\begin{array}{r}10 \cdot 8 \\
4 \cdot 5\end{array}$ \\
\hline $\begin{array}{l}\text { Broad-leaved wood- } \\
\text { land (Dunottar) }\end{array}$ & $\begin{array}{l}2-4 \text { in. } \\
12-15 \text { in. }\end{array}$ & $\begin{array}{l}1 / 25,000 \\
1 / 25,000\end{array}$ & $\begin{array}{l}98 \\
76\end{array}$ & $\begin{array}{r}9 \\
11\end{array}$ & $\begin{array}{c}9 \cdot 5 \\
15\end{array}$ \\
\hline $\begin{array}{l}\text { Agricultural 3rd year } \\
\text { year grass (Stonehaven) }\end{array}$ & $0-6 \mathrm{in.}$ & $1 / 250,000$ & 131 & 21 & 16 \\
\hline
\end{tabular}


Table 2. The morphological characters of soil bacteria and the constituent sugars of the polysaccharides synthesized by them

\begin{tabular}{|c|c|c|c|}
\hline \multicolumn{2}{|l|}{ Soil sample } & \multirow[b]{2}{*}{ Morphology } & \multirow[b]{2}{*}{$\begin{array}{l}\text { Components of the } \\
\text { polysaccharides }\end{array}$} \\
\hline Location and type & Depth & & \\
\hline Dinnet Moor & Layer $A_{2}$ & $\begin{array}{l}\text { Spore former, Group } 1 \\
\text { Short non-sporing rod } \\
\text { Short non-sporing rod } \\
\text { Spore former, Group } 1 \\
\text { Spore former, Group } 1\end{array}$ & $\begin{array}{l}\text { Fructose } \\
\text { Glucose, mannose, } \\
\text { rhamnose, uronic acid } \\
\text { Glucose, uronic acid } \\
\text { Fructose } \\
\text { Fructose }\end{array}$ \\
\hline & Layer $B_{1}$ & $\begin{array}{l}\text { Spore former, Group } 2 \\
\text { Short non-sporing rod } \\
\text { Spore former, Group } 1 \\
\text { Spore former, Group } 1\end{array}$ & $\begin{array}{l}\text { Fructose, glucose, } \\
\text { mannose, uronic acid } \\
\text { Glucose, mannose, } \\
\text { rhamnose, uronic acid } \\
\text { Glucose, uronic acid } \\
\text { Glucose, uronic acid }\end{array}$ \\
\hline $\begin{array}{l}\text { Tilliecorthy; agricul- } \\
\text { tural soil }\end{array}$ & $12-15$ in. & $\begin{array}{l}\text { Spore former, Group } 2 \\
\text { Spore former, Group } 2\end{array}$ & $\begin{array}{l}\text { Fructose, glucose, } \\
\text { uronic acid } \\
\text { Glucose, mannose, } \\
\text { uronic acid } \\
\text { Glucose, uronic acid }\end{array}$ \\
\hline $\begin{array}{l}\text { Dunottar Woods; } \\
\text { broad-leaved woodland } \\
\text { soil }\end{array}$ & $2-4$ in. & $\begin{array}{l}\text { Spore former, Group } 2 \\
\text { Short non-sporing rod } \\
\text { Medium non-sporing rod } \\
\text { Spore former, Group } 2 \\
\text { Short non-sporing rod } \\
\text { Spore former, Group } 1 \\
\text { Short non-sporing rod }\end{array}$ & $\begin{array}{l}\text { Fructose, glucose, } \\
\text { mannose, uronic acid } \\
\text { Glucose, mannose, } \\
\text { rhamnose, uronic acid } \\
\text { Glucose, mannose, } \\
\text { uronic acid } \\
\text { Glucose, mannose, } \\
\text { uronic acid } \\
\text { Glucose, uronic acid } \\
\text { Fructose } \\
\text { Glucose, uronic acid }\end{array}$ \\
\hline & $12-15$ in. & $\begin{array}{l}\text { Short non-sporing rod } \\
\text { Short non-sporing rod } \\
\text { Short non-sporing rod } \\
\text { Short non-sporing rod } \\
\text { Short non-sporing rod } \\
\text { Short non-sporing rod }\end{array}$ & $\begin{array}{l}\text { Glucose, uronic acid } \\
\text { Glucose, mannose, } \\
\text { rhamnose, uronic acid } \\
\text { Fructose, glucose, } \\
\text { uronic acid } \\
\text { Glucose, uronic acid } \\
\text { Glucose, uronic acid } \\
\text { Glucose, uronic acid }\end{array}$ \\
\hline $\begin{array}{l}\text { Stonehaven; agricul- } \\
\text { tural soil }\end{array}$ & $0-6 \mathrm{in.}$ & $\begin{array}{l}\text { Spore former, Group } 1 \\
\text { Short non-sporing rod } \\
\text { Spore former, Group } 1 \\
\text { Spore former, Group } 1 \\
\text { Pleomorphic type } \\
\text { Short non-sporing rod } \\
\text { Short non-sporing rod } \\
\text { Short non-sporing rod } \\
\text { Pleomorphic rods } \\
\text { Pleomorphic rods } \\
\text { Medium non-sporing rod } \\
\text { Pleomorphic rods } \\
\text { Spore former, Group } 1 \\
\text { Spore former, Group } 1 \\
\text { Spore former, Group } 1\end{array}$ & $\begin{array}{l}\text { Fructose } \\
\text { Glucose, uronic acid } \\
\text { Fructose } \\
\text { Fructose } \\
\text { Fructose } \\
\text { Glucose, uronic acid } \\
\text { Glucose, uronic acid } \\
\text { Glucose, mannose, } \\
\text { rhamnose, uronic acid } \\
\text { Glucose, uronic acid } \\
\text { Glucose, uronic acid } \\
\text { Fructose, glucose, } \\
\text { uronic acid } \\
\text { Glucose, mannose, } \\
\text { uronic acid } \\
\text { Glucose, uronic acid } \\
\text { Fructose } \\
\text { Fructose }\end{array}$ \\
\hline
\end{tabular}


bacteria, their morphological character, and the constituent sugars of the polysaccharides synthesized by each. The spore-forming bacteria have been divided into groups after Smith, Gordon \& Clark (1946). The pleomorphic organisms were similar morphologically to those described by Conn \& Dimmick (1947) under the genus Arthrobacter.

\section{DISCUSSION}

It is apparent from Table 1 that gum-producing bacteria are present in reasonable numbers in all the soils studied, and from Table 3 that the levan and glucose-uronic types of polysaccharides predominate in the soils studied. A glucose-mannose-uronic type is also present. A group of organisms synthesizing a polysaccharide containing rhamnose is moderately prevalent and well distributed. Such a polysaccharide has not hitherto been isolated from a non-pathogenic bacterium.

\section{Table 3. The different types of polysaccharide gum produced by soil bacteria; distribution among the soils}

The different types of bacterial gums give on hydrolysis the following sugars: $A$, fructose; $B$, fructose, glucose, uronic acid; $C$, fructose, glucose, mannose, uronic acid; $D$, glucose, uronic acid; $E$, glucose, mannose, uronic acid; $F$, glucose, mannose, rhamnose, uronic acid.

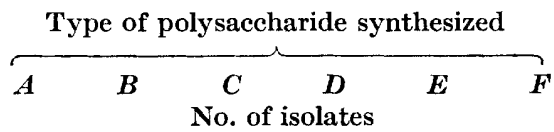

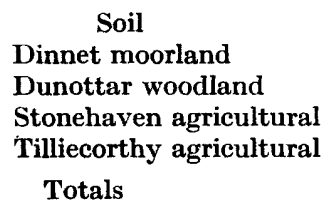

$\begin{array}{rrrrrrr}\text { 3 } & 0 & 1 & 3 & 0 & 2 & \text { Total } \\ 1 & 1 & 1 & 6 & 2 & 2 & 13 \\ 6 & 1 & 0 & 6 & 1 & 1 & 15 \\ 0 & 1 & 0 & 1 & 1 & 0 & 3 \\ 10 & 3 & 2 & 16 & 4 & 5 & 40\end{array}$

It is known that the Group 1 bacilli of Smith et al. (1946) produce levans (Harrison, Tarr \& Hibbert, 1930; Challinor, Haworth \& Hirst, 1934; Lyne, Peat \& Stacey, 1940; Forsyth \& Webley, 1949). Group 2 bacilli produce glucose-uronic and glucose-mannose-uronic types (Forsyth \& Webley, 1949). Soil organisms such as Rhizobium spp. and Azotobacter spp. (Cooper, Daker \& Stacey, 1938) and possibly the Cytophaga group (Walker \& Warren, 1938) also produce polysaccharides of the glucose-uronic type. Martin (1945) has isolated from soil non-spore-forming rods which synthesize polysaccharides of this type.

Table 4. Morphology of soil bacteria and type of polysaccharide synthesized

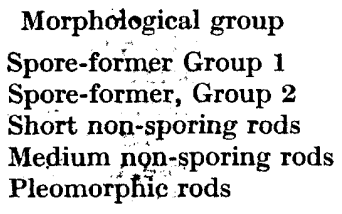

Morphotogical group

Spore-former Group 1

Spore-former, Group 2

Medium non-sporing rods

Pleomorphic rods

\begin{tabular}{|c|c|c|c|c|c|c|}
\hline$A$ & $\boldsymbol{B}$ & $C$ & $D$ & $E$ & $\boldsymbol{F}$ & Total \\
\hline 9 & 0 & 0 & 3 & 0 & 0 & 12 \\
\hline 0 & 1 & 2 & 0 & 2 & 0 & 5 \\
\hline 0 & 1 & 0 & 11 & 0 & 5 & 17 \\
\hline 0 & 1 & 0 & 0 & 1 & 0 & 2 \\
\hline 1 & 0 & 0 & 2 & 1 & 0 & 4 \\
\hline
\end{tabular}


When a comparison is made of the morphological characteristics and the type of polysaccharide synthesized by the soil bacteria, it is seen (Table 4) that there is no clear correlation between morphology and type of polysaccharide synthesized; different types of polysaccharide are produced by members of a given morphological group. The results for the spore-formers are in close agreement, as regards the type of polysaccharide produced within each group, with the findings of Forsyth \& Webley (1949) for type cultures of species of the genus Bacillus. The predominant group of short non-spore-forming rods produce gums chiefly of the glucose-uronic type.

\section{REFERENCES}

Challinor, S. W., Haworth, W. N. \& Hirst, E. L. (1934). Polysaccharides. Part XVII. The constitution and chain length of levan. J. chem. Soc. p. 676.

Cons, H. J. \& Dimmick, I. (1947). Soil bacteria similar in morphology to Mycobacterium and Corynebacterium. J. Bact. 54, 291.

Cooper, E. A. \& Preston, J. F. (1937). Polysaccharide synthesis by nitrogen-fixing organisms. J. Soc. chem. Indus., Lond., 56, 1 T.

Cooper, E. A., Daker, W. D. \& Stacey, M. (1938). Enzyme formation and polysaccharide synthesis by bacteria. III. Polysaccharides produced by 'nitrogenfixing organisms'. Biochem. J. 32, 1752.

Cutler, D. W., Crump, L. M. \& Sandon, H. (1922). A quantitative investigation of the bacterial and protozoan population of the soil with an account of the protozoan fauna. Philos. Trans. B, $211,317$.

Forsy'rh, W. G. C. (1947). Studies on the more soluble complexes of soil organic matter. I. Method of fractionation. Biochem. J. 41, 176.

ForsYTh, W. G. C. (1948). Colour reagents for the paper chromatography of sugars. Nature, Lond., 161, 239.

Fonsyth, W. G. C. \& Webley, D. M. (1949). Polysaccharides synthesized by aerobic mesophilic spore-forming bacteria. Biochem. J. 44, 455.

Fuller, W. H. (1947). Decarboxylation rate of uronic groups contained in soil organic matter, plant gums of known constitution, plant materials and microbial products. Soil Sci. 64, 183.

Harrison, F. C., Tarr, H. L. A. \& Hibbert, H. (1930). Reactions relating to carbohydrates and polysaccharides. XXXIII. The synthesis of polysaccharides by bacteria and enzymes. Can. J. Res. 3, 449.

Lyne, R. R., Peat, S. \& Stacey, M. (1940). Polysaccharides. XXXIV. The constitution of certain levans formed by bacterial action. J. chem. Soc. p. 237.

Martin, J. P. (1945). Some observations on the synthesis of polysaccharides by soil bacteria. J. Bact. $50,349$.

Martin, J. P. (1946). Microorganisms and soil aggregation. II. Influence of bacterial polysaccharides on soil structure. Soil Sci. 61, 157.

Normax, A. G. (1942). Problems in the chemistry of soil organic matter. Proc. Soil Sci. Soc. Amer. 7, 7.

Partridge, S. M. (1946). Application of the paper partition chromatograms to the qualitative analysis of reducing sugars. Nature, Lond., 158, 270.

Partridge, S. M. (1948). Filter paper partition chromatography of sugars. I. General description and application to the qualitative analysis of sugars in apple juice, egg white and foetal blood of sheep. Biochem. J. 42, 238.

Smith, N., Gordon, R. E. \& Clark, F. (1946). Aerobic mesophilic spore-forming bacteria. Misc. Publ. U.S. Dep. Agric. No. 559.

Walker, E. \& Warren, F. L. (1938). Decomposition of cellulose by Cytophaga. Biochem. J. 32, 31.

(Received 17 January 1949) 